Relations industrielles

Industrial Relations

\title{
IV - Methods for Reform in Structure Proposed Solutions
}

\section{Marcel Clément}

Volume 3, numéro 8, avril 1948

URI : https://id.erudit.org/iderudit/1023616ar

DOI : https://doi.org/10.7202/1023616ar

Aller au sommaire du numéro

Éditeur(s)

Département des relations industrielles de l’Université Laval

ISSN

0034-379X (imprimé)

1703-8138 (numérique)

Découvrir la revue

Citer cet article

Clément, M. (1948). IV - Methods for Reform in Structure: Proposed Solutions.

Relations industrielles / Industrial Relations, 3(8), 122-124.

https://doi.org/10.7202/1023616ar

Tous droits réservés @ C Département des relations industrielles de l’Université Laval, 1948
Ce document est protégé par la loi sur le droit d'auteur. L'utilisation des services d'Érudit (y compris la reproduction) est assujettie à sa politique d'utilisation que vous pouvez consulter en ligne.

https://apropos.erudit.org/fr/usagers/politique-dutilisation/ 
Notre législateur a donc fait de la durée et du mode de prorogation d'une convention une règle de droit public dont les parties ne peuvent se libérer; il a donné à cette disposition un tel caractère pour assurer Ia fixation de la période de substitution d'une nouvelle association à celle reconnue. La loi a déterminé cette période en ne se référant qu'au cas d'existence d'une convention, quoique cette dernière ne soit pas obligatoire et que les conditions de travail puissent résulter d'une sentence arbitrale ou encore d'un règlement d'atelier, le texte n'obligeant l'employeur qu'à négocier et non à signer une convention collective.

La loi pourrait fixer suivant un autre mode la période pour substitution d'une association à celle reconnue; elle pourrait accorder cette substitution du 300ième au 340ième jour de la date d'entrée en vigueur de la convention et, à chaque année subséquente, durant la période entre l'anniversaire de ces dates, cette règle s'appliquant également au cas de sentences arbitrales ou de règlements d'atelier agréés par une association reconnue.

Une telle modification législative rendrait inutile l'article 15; les parties pourraient alors convenir à leur gré, ce qui est la norme, de la duréc et du mode de prorogation de leur convention. collective, elles ne la verraient pas devenir sans effet pour avoir omis un seul mot dans une clause à réảaction impérative.

Les légistes, pas plus que les justiciables, n'a1ment les clauses drastiques et ils sont heureux d'en proposer la suppression lorsque sans elles la vraie physionomie d'une institution juridique, peut être conservée.

IV-METHODS FOR REFORM IN STRUCTURE

\section{PROPOSED SOLUTIONS}

\section{Marcel CLÉMENT}

In order to make a rapid survey of new structural forms in the enterprise we will start from a particular concrete observation. It often happens in setting up a profit-sharing scheme that certain individuals object, alleging the dangers of paternalism. Such and such a form of sharing has been looked upon with suspicion by quite well informed persons simply because they see in profit-sharing a «dead-end». (The moral aspect of this problem is treated by M. l'abbé Dion in another connection.) This point of view reminds us of the man who refuses to walk for fear of taking a false step.

Let us admit at once that timidity of this sort presents real dangers. In the very interest of social peace it is necessary that the changeover from the liberal structure to the community structure should depend upon the initiative of the employer. A profit-sharing contract that establishes conditions eliminating discretionary powers over the bonus, confers upon its signing, new rights on the worker, when it is signed. But up until this moment the contract depends on the pleasure of the entreprencur. To say this is in no way to imply an attitude of paternalism. Rather, it is asking the heads of the enterprise to consider the measure of their responsibility at a moment when the initiative still depends on them,
It is by no means certain that this will always be so. Social peace may depend upon the reasoning and good common sense of the workmen. But, it may also depend upon the loyalty and far-sightedness of the employer. To call this loyalty and this far-sightedness paternalism is to confuse those concerned and consequently, to bewilder the better spirits among them. This is why we have insisted so often repeatedly on the necessity of that inner conversion «by which the employer acknowledges his employees as younger brothers for whom he is responsible ». Such a straight-forward outlook could never be mistaken for paternalism or a trading on the confidence of the workman.

In consideration of the above, three rules should govern all structural reform:

1 - In no form of profit-sharing should the question of the salary enter in, whether it be equal to or above the necessary minimum.

2 - The preference given such and such a form of participation should principally depend upon the size and the character of each enterprise even where it appears that such and such other system might be preferable.

3 - Further still, profit-sharing should not be a « ready-made garment » but one « made-toprder», Thus, modifications or additions can 
be brought to each formula always taking into account a particular professional psychology or a new technique of production, etc. There have also been cases of two methods being combined. What matters is the intention, the fairness and the realism of execution, not the content of the formula used.

These points accepted, we propose to review, as briefly and clearly as possible, the different methods which have been successfully tried out.

\section{1 - Profit Sharing}

(The Romanet System '

Profit sharing is something whose disadvantages have often been enumerated and are now acknowledged to be not those of the system itself but those of the spirit in which that system has been applied. It is not then of fraudulent imitations, which may quite rightly be criticized, but of real participation that we intend to speak. Of that, for exemple, which M. Romanet and innumerable other European industrialists have shown to be not only possible but successful!

Monsieur Romanet is a man who inspires confidence. We owe to him the boon of the Compensation Fund which has permitted, in France, the installation of Family Allowances. To encourage the spread of these Funds to all enterprises Monsieur Romanet started the movement and has personally set the example by founding, with certain of his friends, the first Compensation Fund. The result has surpassed all hopes. The renewal of family life has been helped as a result fo this measure, now obligatory, and its moral consequences are thus incalculable.

Will not Monsieur Romanet experience in the long run a similar exceptional success with the other great project of his career as an employer - the sharing of the workers in the profits of the enterprise? It is surely not unreasonable to think so when one considers that he has applied in his business and with constant success, the same formula since 1927, that is to say for twenty-one years.

Monsieur Komanet starts with the observation of facts. He considers that the factors of the enterprise are :

-Capital, necessary for the acquisition of immovables - land, buildings and furnishings, tools, raw material and working capital for the enterprise.
-Labour, consisting of :

a-Management personnel which assures the control of the enterprise through the choice and putting into effect of the proper means of realizing the desired ends.

b-Production personnel, which, by uniting the interest of the mind and the effort of the body, assures the adaptation of raw materials to the satisfying of human needs.

To each of these factors are awarded three kinds of compensation:

-the ordinary or basic salary

-the adjusted or reserve salary

-a variable bonus or share in the profits. After the final stock-taking, the profit is distributed in the following manner: 5 to $10 \%$ levied for group security purposes, the rest divided between capital and labour.

Thus, capital collects :

1-the ordinary interest based on the current rate;

2-an annual reserve which goes to the reserve fund to provide for deficits and future risks;

3-a bonus, that is to say, a share in the net profit as shown in the financial statement for its part Labour-management and production personnel-collects:

1-the usual salary, a basic remuneration which takes into account professional qualifications and individual aptitudes;

2-an adjusted salary, whether or not stipulated by the law, family allowances, paid holidays and insurance;

3-a bonus, i.e. a share of the net profits as shown by the financial statement.

The distribution of the bonus is necessarily the most difficult part of the operation. We borrow from Monsieur Paul Chas ${ }^{1}$ the following analysis, remarkable for the clarity of its three hypotheses:

1-If the total net profit is available it is distributed among the different classes of workers in proportion to the amounts which they have received during the year as wages. However, in order to remunerate the effort, the value and the responsabilities incurred the sums apportioned to personnel are determined by a co-efficient of increment, a special co-efficient permitting the taking into account of seniority and family expenses. In the same way the interest of Capital may be increased if the risk element is important and if the holders of capital are at the same time promoters of the enterprise.

(1) P. Chas. "Le Rémunération de Travail", in "Chronique Sociale de France", janvier 1946. 
2-If the profits are converted partly into liquid cash, partly into purchases of land, buildings, machines, stock and additional working capital, the available portion is distributed as stated above. As for the other portion it is shown in the individual bonus book. The share of each individual share-holder or participating member ot personnel ${ }^{2}$ is calculated with the same co-efficients as for the cash distributions. It becomes a part of interest-bearing capital and can be distributed only if the possibilities of the enterprise permit it or in certain cases of absolute necessity.

3 -If there is a loss in the fiscal period it is made good by a levy taken first from the reserve constituted for the purpose, then on the bonus recorded in the bonus book of each participant, ${ }^{3}$ and finally, on the capital fund itself if necessary. Consequently, at the end of the first fiscal period showing profits the situation of capital is adjusted so as to bring it back to the original figures. The correction made, the three factors-capital, mana;

(2) Those members of the personnel having less than 2 years seniority do not have the right to this remuneration unless their professional value has given them from their arrival, this privilege.

(3) Instead of deductions in the bonus book, an account can be opened - "losses redeemable" - which future profits pay off in order of priority. gement and labour-once more divide the profits whether in the form of a distribution of money or as an entry in the bonus record.

These are the general lines of the formula. Needless to say, it is supposed that honesty and prudence govern the determination of the several percentages and that the perfect accuracy of the accounts is realized, and evident to the eyes of all. With this in view, Monsieur Romanet has handed over the control to the hands of sworn commissioners. Complete confidence has been accorded to the scheme so much so that workers spontaneously ask to invest in the enterprise in the form of shares or of deposits recorded in the bonus record book, those profits which are due them. ${ }^{4}$

To terminate our discussion let us point out that at the present time, in France, more than ninety firms of different types and of varying importance have adopted this plan and declare themselves fully satisfied. This is really «to temper the labour contract by elements borrowed from the partnership agreement ».

(4) For more detail read E. Romanet: "Participation des salariés aux résultats obtenus dans les entreprises", Address the author, 17 cours Jean Jaurès, Grenoble (Isère), France.

\section{THE RENEWAL CLAUSE OF COLLECTIVE LABOUR AGREEMENTS}

\section{Georges-Michel GIROUX}

The Legislature, by means of the Labour Relations Act, has made enactments dealing with the duration and the mode of renewal of collective labour agreements. Let us quote the provision relating thereto:

《 15-No collective agreement shall be made for more than one year, but it may be agreed that it shall be automatically renewed for a similar period, and so on, upon failure by one of the parties to give a written notice to the other party within a delay which shall not be more than sixty days nor less than thirty days prior to the expiration of each period.»

What is the juridical ambit of this enactment? It is precisely the object of the present study.

First of all, it would be fitting to recall the situation that existed before the promulgation of this Act and to emphasize the principles which have caused the new departure.
Under the Professional Syndicates Act, the collective labour agreement became a juridical entity; the Act defined the nature of the collective agreement and determined the scope of the obligations of the individuals bound by or subject to such agreement. Some provisions of the French Labour Code (s. 31 \& seq.) were embodied in this legislation, but the principal articles giving this institution its specific character, were omitted.

Only such agreements as were signed by duly incorporated syndicates were considered as binding; those entered into by unincorporated labour unions were considered as «gentlemen's agreements » i.e. unenforceable agreements.

The law gave the parties full liberty of limiting the duration of the agreement. Our Legislator, contrary to the French Code, neither stated that the agreement with a limited duration could not be made for more than five years (s. 31 g.), nor that such agreement would, at the date of its expiration, remain in force as a non-limited agree- 